\title{
Mudar a cultura ou o comportamento?
}

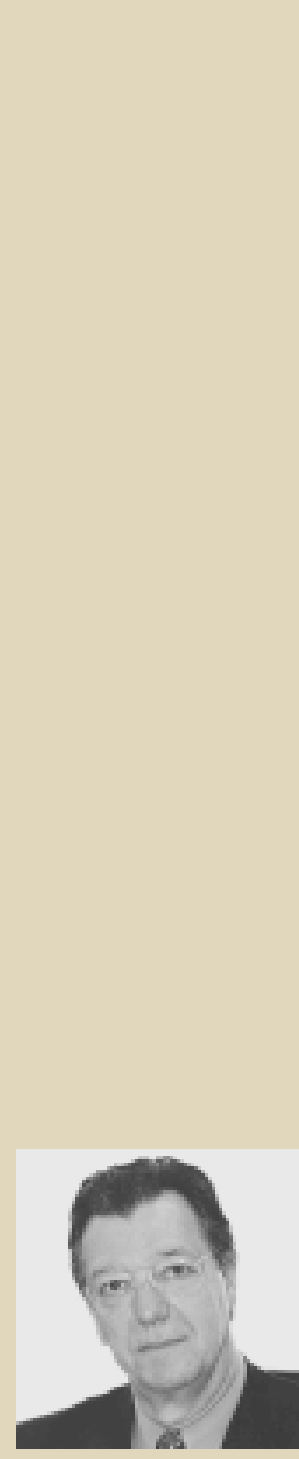

Carlos Osmar Bertero FGV-EAESP

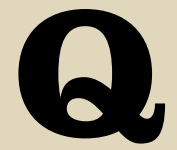

uando, em uma empresa ou sociedade, a situação parece obscura mas não se sabe exatamente o que está ocorrendo, nem se sabe o quefazer para queaconteçam as coisas que tod os desejam, ouve-se sempre dizer que a cultura deve mudar. Nas organizações, esse discurso surge particularmentequando se abordam as mudanças em estratégia, estrutura, processos e operações. Geralmente, vem embalado em um pacote que ganha o nome de changemanagement. No entanto, poucos têm uma idéia exata do que seja cultura.

A cultura forma-se ao longo do tempo, em um processo histórico. Não resulta de uma deliberação. Por que há povos que prezam o bemestar material enquanto outros se voltam para o espírito? Por que algumas sociedades prezam 0 trabalho enquanto outras o consideram uma maldição reservadaàs classes "inferiores"? Por quealgumas empresas desenvolvem uma cultura eficiente e flexível enquanto outras não conseguem se adaptar a um mundo em constantemudança? Tudo isso pode ser apenas parcialmente explicado. A análise cultural de empresas costuma apenas expor asituação existente, não transformá-la. Ao longo da história de uma empresa, não houve ninguém que tenha premeditado ou deliberado criar uma cultura com determinados valores, crenças e atitudes. Simplesmente aconteceu.

Portanto, quando se fala em "mudar a cultura", deve-se ter em mente que não se pode mudar algo cuja origem se desconhece. A questão é: a que se referem os "relatos de sucesso" sobre a mudança na cultura que enchem os relatórios de consultoria? Eles indicam apenas mudanças de comportamento. Embora seja de bom-tom criticar o behaviorismo - instrumento do autoritarismo, desrespeitador do ser humano, etc. -, ele ainda tem uso freqüente. 0 fato é que não interessam os valores, crenças, opiniões, visões de mundo e critérios éticos que as pessoas possam ter; 0 que 0 administrador deseja é que elas se comportem de maneira organizacionalmente conveniente. Se isso acontecer, elas serão recompensadas com promoções, salários e carreiras. Caso contrário, não haverá recompensa e, no limite, irá se chegar à exclusão da pessoa dos quadros da organização.

Com isso, adotam os comportamentos desejados aqueles que prezam sua carreira ou que precisam do emprego. E a experiência demonstra que, apesar da incorreção política, o behaviorismo - como forma de adequar comportamentos a metas, estruturas e processos empresariais - funciona. Basta perguntar a gestores de mudança - change managers - e agentes de mudanças radicais - turnarounders.

Restauma última questão, que interessaria a psicólogos, sociólogos e antropólogos: ao longo do tempo, o comportamento pode modelar valores, crenças e visões de realidade, gerando culturas? Q ualquer que seja a resposta, ela não tem grande importância: mesmo que seja positiva, 0 processo seria muito lento. Para o administrador, basta que se mude o comportamento. 0 resto é retórica e jogo de cena. 